University of Nebraska - Lincoln

DigitalCommons@University of Nebraska - Lincoln

Faculty Publications from the Harold W. Manter Laboratory of Parasitology

$12-2002$

\title{
The Birds of St. Matthew Island, Bering Sea
}

\author{
Kevin Winker \\ University of Alaska Museum \\ Daniel D. Gibson \\ University of Alaska Museum \\ Arthur L. Sowls \\ Alaska Maritime National Wildlife Refuge \\ Brian E. Lawhead \\ $A B R$, Inc. \\ Philip D. Martin \\ United States Fish and Wildlife Service \\ See next page for additional authors
}

Follow this and additional works at: https://digitalcommons.unl.edu/parasitologyfacpubs

Part of the Parasitology Commons

Winker, Kevin; Gibson, Daniel D.; Sowls, Arthur L.; Lawhead, Brian E.; Martin, Philip D.; Hoberg, Eric P.; and Causey, Douglas, "The Birds of St. Matthew Island, Bering Sea" (2002). Faculty Publications from the Harold W. Manter Laboratory of Parasitology. 319.

https://digitalcommons.unl.edu/parasitologyfacpubs/319

This Article is brought to you for free and open access by the Parasitology, Harold W. Manter Laboratory of at DigitalCommons@University of Nebraska - Lincoln. It has been accepted for inclusion in Faculty Publications from the Harold W. Manter Laboratory of Parasitology by an authorized administrator of DigitalCommons@University of Nebraska - Lincoln. 


\section{Authors}

Kevin Winker, Daniel D. Gibson, Arthur L. Sowls, Brian E. Lawhead, Philip D. Martin, Eric P. Hoberg, and Douglas Causey 


\title{
THE BIRDS OF ST. MATTHEW ISLAND, BERING SEA
}

\author{
KEVIN WINKER, ${ }^{1,7}$ DANIEL D. GIBSON,${ }^{1}$ ARTHUR L. SOWLS, ${ }^{2}$ \\ BRIAN E. LAWHEAD, ${ }^{3}$ PHILIP D. MARTIN,${ }^{4}$ ERIC P. HOBERG,${ }^{5}$ \\ AND DOUGLAS CAUSEY ${ }^{6}$
}

\begin{abstract}
St. Matthew Island $\left(60^{\circ} 24^{\prime} \mathrm{N}, 172^{\circ} 42^{\prime} \mathrm{W}\right)$ and its small nearby satellites, Hall Island and Pinnacle Rock, are isolated in the northcentral Bering Sea. This infrequently visited location occupies a geographic position with a deep Bering Land Bridge history and is in an area of interdigitation of the Old World, New World, and Beringian avifaunas. It is known for its three Beringian endemics, a bird (McKay's Bunting, Plectrophenax hyperboreus), a small mammal, and a plant. This level of endemism is striking for a high-latitude island. The only previous summary of the avifauna of St. Matthew island (Hanna 1917) included 37 species. Our report considers more than 125 species and synthesizes data on presence and absence, abundance, and phenology. Because visits have been infrequent and concentrated during summer, our understanding of migration in this region remains poor, but the area is clearly affected by both the Old and New world migration systems. There is sufficient evidence to show that some profound changes among the island's breeding birds have occurred during the past century. In particular, the breeding range of Glaucous-winged Gulls (Larus glaucescens) has been extended north to include St. Matthew, a change that is correlated with a northward shift in the extent of sea ice (Maslanik et al. 1996). King and Common eiders (Somateria spectabilis and S. mollissima) also have shown substantial changes in summer abundance. Other changes in the summer avifauna (e.g., among shorebirds) may reflect the dynamics of edge-of-range phenomena. Because of its central position in a region undergoing profound climate change and its demonstrated track record in showing avifaunal shifts, St. Matthew Island may represent an important bellwether for monitoring the biological effects of further climate change in the northern Bering Sea. Received 31 July 2001, accepted 15 April 2002.
\end{abstract}

Isolated in the northcentral Bering Sea at $60^{\circ} 24^{\prime} \mathrm{N}, 172^{\circ} 42^{\prime} \mathrm{W}$, St. Matthew Island and its small nearby satellites, Hall Island and Pinnacle Rock, occupy a central geographic position relative to the breeding ranges and seasonal movements of the different bird faunas to the north (St. Lawrence Island and Bering Strait), south (Pribilof and Aleutian islands), east (the Alaska mainland), and west (Kamchatka, the Koryak Highlands, Gulf of Anadyr, and Chukotsk Peninsula). This position (Fig. 1) provides a unique perspective on the dynamic and complex interdigitation of the northern Palearctic and Nearctic avifaunas and

${ }^{1}$ Univ. of Alaska Museum, 907 Yukon Dr., Fairbanks, AK 99775-6960, USA.

${ }^{2}$ Alaska Maritime National Wildlife Refuge, 2355 Kachemak Bay Dr., Suite 101, Homer, AK 996038021, USA.

${ }^{3}$ ABR, Inc., P.O. Box 80410, Fairbanks, AK 99708 0410, USA.

${ }^{4}$ U.S. Fish and Wildlife Service, 101 12th Ave., Box 19, Room 110, Fairbanks, AK 99701, USA.

${ }^{5}$ USDA Agricultural Research Service, BARC East, No. 1180, 10300 Baltimore Ave., Beltsville, MD 20705, USA.

${ }^{6}$ Museum of Comparative Zoology, Harvard Univ., 26 Oxford St., N Cambridge, MA 02138, USA.

${ }^{7}$ Corresponding author; E-mail: ffksw@uaf.edu of both of these with the endemic Beringian avifauna. The phenologies of events such as reproduction, migration, and overwintering status in this region are poorly known. Further, this region is likely to undergo greater than average responses to global warming (Myneni et al. 1997), suggesting that the timing of these events may change in the future.

St. Matthew Island (including Hall Island and Pinnacle Rock) is perhaps most noteworthy biologically for constituting the home of an endemic mammal (St. Matthew Island vole, Microtus abbreviatus), an endemic plant (Artemisia globularia var. lutea), and the entire breeding range of a species of bird (McKay's Bunting, Plectrophenax hyperboreus). In addition, the nominate subspecies of the Rock Sandpiper (Calidris ptilocnemis ptilocnemis) breeds only here and on the Pribilof Islands, as does a subspecies of the Graycrowned Rosy-Finch (Leucosticte tephrocotis umbrina). This level of endemism is surprising for a small land area at such a high latitude, but no doubt reflects the deep temporal history of a once larger Beringia.

These islands were an unglaciated refugium during past ice ages (Hamilton et al. 1986). Pollen sequences from St. Lawrence Island 


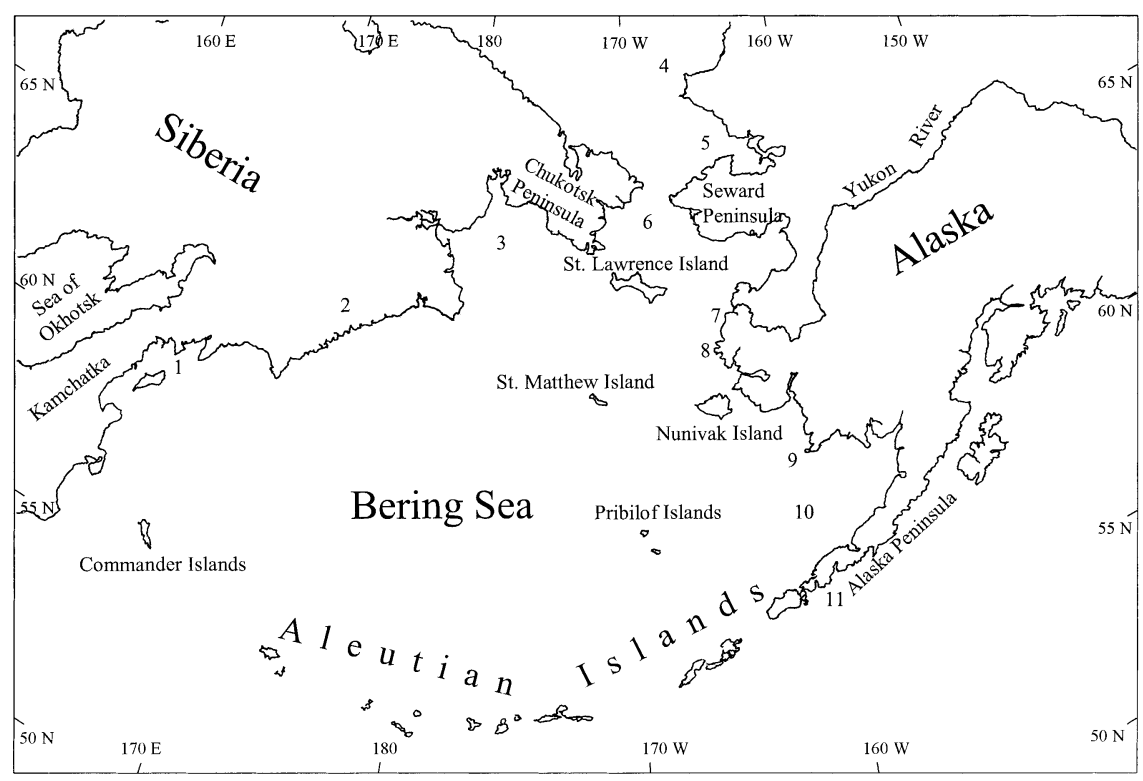

FIG. 1. St Matthew Island (center) and the greater Beringian region, including most locations mentioned in the text. Numerical locations are (1) Karaginskiy Bay, (2) Koryak Highlands, (3) Gulf of Anadyr, (4) Cape Lisburne, (5) Kotzebue Sound, (6) Bering Strait, (7) Yukon-Kuskokwim Delta, (8) Cape Romanzof, (9) Cape Newenham, (10) Bristol Bay, and (11) Shumagin Islands.

and the Pribilof Islands, to the north and south, respectively, reveal a very long unglaciated history for the region $(30,000-70,000$ years), with full-glacial records suggestive of xeric tundra with some indication (from an unknown source) of spruce, birch, and alder (Barnosky et al. 1987). The islands have been protected since the Bering Sea Bird Reservation was established in 1909, and they are presently contained within the Alaska Maritime National Wildlife Refuge.

Avian study has been conducted only sporadically, and usually briefly, at this remote locality. No summary of the avifauna of this island group has appeared in the ornithological literature since Hanna (1917). The first ornithological venture on these islands may have been that of von Kittlitz, who took a few specimens there in the mid-1800s (Rausch and Rausch 1968). The islands first came to prominent ornithological attention when Hall Island was discovered to be the breeding ground of McKay's Bunting (Ridgway 1886, Townsend 1887). Albert K. Fisher and others visited on 14-15 July 1899 as part of the Harriman Expedition (Goetzmann and Sloan 1982), but their ornithological observations were never published. During 8-13 July 1916, G. Dallas Hanna visited under the aegis of the U.S. Biological Survey; his published report (Hanna 1917), which included A. K. Fisher's notes from 1899, summarized the 37 species then known from the islands. Ira N. Gabrielson was the next ornithologist to visit, briefly, on 8-9 July 1940 (Gabrielson 1944), and he visited briefly again on 7 August 1946 (Gabrielson and Lincoln 1959). The unpublished notes of Frank L. Beals (copy at Univ. of Alaska Museum) were an invaluable source of additional information. Beals was at St. Matthew with the U.S. Fish and Wildlife Service from 24 June to 16 August 1944. His notes include a wealth of useful information, including the notes of Russell V. Anderson, who was on the island with the U.S. Coast Guard from July 1943 to June 1944 and was able to provide glimpses of phenology that could be gathered only by someone on the island throughout the year. Detlef Eisfeld visited the island from 30 June to 20 July 1966 and also made important avian observations. For Klein (1959) in 1957 and Rausch and Rausch (1968) in 1954, a look at St. Matthew's birds was peripheral to their work on mammals. More recently, in response 
to projected development of the island as a logistical base for offshore oil exploration in the Navarin Basin oil and gas lease area, fieldwork conducted in the 1980s produced much useful information on five species of cliffnesting seabirds (Murphy et al. 1987), but only sketchy information on most other avian species.

Hanna's (1917) report considered 37 species; we include 125 and also discuss the status of four others. Our purpose in this study has been to survey and update baseline information on the St. Matthew Island avifauna because of its importance to our understanding of broader regional topics such as Beringia, the crossover of continental avifaunas, and the biological effects of climate change.

\section{METHODS}

Study area.-St. Matthew Island comprises some $470 \mathrm{~km}^{2}(52 \times 9 \mathrm{~km})$ of rolling subarctic tundra (elevations to $430 \mathrm{~m}$ ) with freshwater lakes and streams, gently sloping beaches, and precipitous seacliffs. With its two satellites, Hall Island $(9 \times 3 \mathrm{~km})$ and Pinnacle Rock, St. Matthew is "barren, treeless, uninhabited and surrounded by dangerous and poorly charted waters" (Hanna 1917:403).

Methods.-In the species accounts below, phylogenetic sequence and scientific and English names follow AOU checklist (American Ornithologists' Union 1998), subspecies nomenclature follows Gibson and Kessel (1997), and status and abundance terminology follow Kessel and Gibson (1978). We summarize existing phenological information while recognizing that it is incomplete. Unattributed data are those of the authors. "UAM unpubl." refers to unpublished Alaska bird records archived at the Univ. of Alaska Museum. Parenthetical subspecific names indicate a subspecies that is inferred by range; parenthetical "ssp." indicate that it is unreasonable to infer subspecies without specimens. Taxa in square brackets we consider to be unsubstantiated records. The complex zoogeography of the avifauna in this region often requires reference to broader regional status to place existing data in context. Where necessary, we include brief summaries.

In the past, midsummer occurrences of many species at northerly latitudes were inferred to represent breeding simply because of presence at that season. We now know that midsummer occurrences in this region regularly include late-migrant stragglers, nonbreeding birds summering just beyond the limits of the breeding range, and early returning failed breeders. Such birds can complicate an assessment of avian status during the breeding season, and presence alone cannot be inferred to be evidence of breeding (e.g., see Johansen 1961, versus American Ornithologists' Union 1957). Where we have no more than circumstantial evidence, therefore, we have been conservative about attributing breeding status to various species on these islands.

\section{ANNOTATED SPECIES LIST}

Gavia stellata (Red-throated Loon). Fairly common breeder. Numerous and nesting in 1916 (Hanna 1917). High counts have included four pairs with six young (July 1944, F. L. Beals). Several nests and adults with young in summer 1982, maximum day count of six (7 June). The only common nesting loon in the Aleutians (Murie 1959), at Nunivak Island (Swarth 1934), and at St. Lawrence Island (Fay and Cade 1959).

Gavia arctica (viridigularis) (Arctic Loon) or G. pacifica (Pacific Loon). Rare in spring and summer. "Arctic" loons occurred from 28 May (1982) to 5 July (1977), usually singly, maximum three (DeGange and Sowls 1978). In Asia, arctica and pacifica breed in sympatry from Chukotsk Peninsula to the Koryak Highlands (Kishchinskii 1980), but arctica alone breeds in Kamchatka and the Sea of Okhotsk (Vaurie 1965). The latter nests at St. Lawrence Island (Fay and Cade 1959) and on the entire Bering coast of the Alaska mainland (Gabrielson and Lincoln 1959), while the former breeds in Alaska only on the Seward Peninsula and in Kotzebue Sound (Douglas and Sowl 1993). Both have been recorded on migration in the Pribilofs (Preble and McAtee 1923, Sladen 1966), and both occur in winter in the Aleutians (UAM unpubl. data).

Gavia immer (Common Loon). Casual in spring and summer. Single adults on ocean 27 to 29 May and 1 June 1982; two on fresh water on 19 June 1982. This primarily New World species nests locally in the Aleutians (Murie 1959), but not in the Commander Islands nor on islands in the Bering Sea. There are a few records at St. Lawrence Island (Fay and Cade 1959; UAM unpubl. data), but it is apparently unknown on Chukotsk Peninsula (Portenko 1973).

Gavia adamsii (Yellow-billed Loon). Rare in spring. One on 2 June 1982. Breeds as far south in Alaska as the Seward Peninsula (Kessel 1989) and St. Lawrence Island (Fay and Cade 1959), and it is a widespread breeder on the Chukotsk Peninsula (Portenko 1973).

Podiceps grisegena (holboellii) (Rednecked Grebe). Rare in spring and casual in summer. Singles seen 27 May through 14 June 
1982 and on 26 June 1982; maximum seen was two (28 May 1982 and 5-6 July 1985). Has nested at St. Lawrence Island (Sealy et al. 1971).

[Phoebastria nigripes (Black-footed Albatross)]. Two reported offshore on 15 July 1957 (Klein 1959).

Fulmarus glacialis rodgersii (Northern Fulmar). Abundant breeder. Made up mostly of light morph birds, the breeding population was estimated at 450,000 birds in 1977 (DeGange and Sowls 1978, Sowls et al. 1978). Recorded as early as about 1 May (1944, R. V. Anderson fide F. L. Beals). Many pairs by 22 May 1982, first egg laid 1 June, and first chick seen 21 July. In 1985 earliest chick ( $<1$ one week old) seen 27 July; earliest unattended chicks 2 August (1986).

Puffinus tenuirostris (Short-tailed Shearwater). Common in summer. Noted by 31 May (1982); maximum count was $6,000+(18$ June 1982).

Oceanodroma furcata (furcata) (Fork-tailed Storm-Petrel). Casual in summer. One on 4 June 1982, two on 24 July 1983, four on 8 August 1983, and one $18 \mathrm{~km}$ east of St. Matthew on 21 August 1985. Species does not nest north of the Aleutian (Sowls et al. 1978) and Commander (Kondratyev et al. 2000) islands.

Phalacrocorax auritus (cincinatus) (Double-crested Cormorant). Casual or accidental in summer. One seen 21 June 1982. Not known to nest closer than Cape Newenham southeastern Bering Sea (Petersen et al. 1991) and the eastern Aleutians (Sowls et al. 1978).

[Phalacrocorax urile (Red-faced Cormorant)]. Attributed, apparently erroneously, to St. Matthew by Nelson (1887). Kessel and Gibson (1994) discussed confusion in published historical accounts of cormorant distributions in Alaska. There have been only scattered records north of the Pribilofs (UAM unpubl. data).

Phalacrocorax pelagicus pelagicus (Pelagic Cormorant). Common breeder, uncommon at other seasons. Arrived as early as about 15 May (1944) and departed before September (1943; both dates R. V. Anderson fide F. L. Beals). In 1977 estimated nesting population was 3,000 (DeGange and Sowls 1978). Breeding phenology included birds carrying nesting materials on 1 June (1983) and 6 June (1982); birds first at nests on 8 June (1982); first eggs on 13 June, first chicks 3 July, and downy chicks and young two-thirds adult size seen by 29 July 1982. Also recorded in midwinter: on 6-7 February 1970, McRoy et al. (1971: 64) noted "one small flock flying offshore."

Anser fabalis (serrirostris) (Bean Goose). Casual in summer. One present 17-23 June 1982. Rare in spring in the Aleutians and casual in spring on Bering Sea islands (Kessel and Gibson 1978). Breeds east to Gulf of Anadyr and Chukotsk Peninsula (Vaurie 1965).

Anser albifrons (frontalis) (Greater Whitefronted Goose). Casual in spring. Two seen with a Canada Goose 24-26 May 1982, and one with six Brant 7-11 June 1982. Casual migrant at St. Lawrence Island (Johnson 1976; UAM unpubl. data).

Chen canagica (Emperor Goose). Casual in summer. Small numbers 4-20 June 1982, and at least two on 8 July 1985 (G. V. Byrd pers. comm.). It is possible that annual movements largely bypass St. Matthew Island. Species is (or was, see Kessel and Gibson 1994 and citations therein) a widespread breeder at St. Lawrence Island (Fay and Cade 1959) and the Yukon-Kuskokwim Delta (King and Dau 1981), and it probably performs a midsummer molt migration from the Y-K Delta to St. Lawrence Island (Jones 1972). Winters throughout the Aleutians (Murie 1959).

Chen caerulescens (caerulescens) (Snow Goose). Casual in spring. Up to 57 seen 22 May through 7 June 1982. Main migration in western Alaska probably bypasses St. Matthew Island; nearest breeding is at Wrangel Island, Chukchi Sea (King and Dau 1981).

Branta canadensis (ssp.) (Canada Goose). Casual in spring. Flock of 20-30 with Snow Geese 22-24 May 1982; four birds on 15 July 1982. Numerous on Bering coast of mainland Alaska (King and Dau 1981), where B. c. minima breeds and parvipes (including taverneri) is a migrant, but only of casual occurrence at St. Lawrence Island (see Sealy et al. 1971). A 1903 specimen of B. c. occidentalis from Gulf of Anadyr seems to be the only record of this species in northeasternmost Asia (Dementiev and Gladkov 1952, Vaurie 1965).

Branta bernicla (nigricans) (Brant). Rare in summer. Up to six seen 6-23 June 1982; two on 11 June 1986 (K. D. Schafer pers. comm.). 
Occurs regularly in spring and summer at St. Lawrence Island (Sealy et al. 1971).

Cygnus columbianus (columbianus) (Tundra Swan). Uncommon in summer; possible breeder. Hanna (1917:408) saw 2-4 swans on lakes "at every landing place" in July 1916. Klein (1959) reported two seen in July and August 1957. One on 9 July 1966 was nesting (D. Eisfeld pers. comm.). Thirteen swans in summer 1977 (DeGange and Sowls 1978) were likely this species. During 1980s swans seen only erratically and in small numbers, maximum five on 3 August 1982. One seen 11 June 1986 was identified (K. D. Schafer pers. comm.) as C. c. bewickii, the Old World subspecies, known in Alaska from only one record (Evans and Sladen 1980).

Anas penelope (Eurasian Wigeon). Rare in spring. Hanna (1917) identified wings nailed to the wall of a derelict cabin. Seen 26 May to 13 June 1982, maximum seven on 31 May. Rare in spring on Bering Sea islands (Kessel and Gibson 1978).

Anas americana (American Wigeon). Casual in spring. Up to four with Eurasian Wigeon 26 May through 4 June 1982; another pair on 1 June 1982. Casual in spring on Bering Sea islands (UAM unpubl. data).

Anas platyrhynchos (platyrhynchos) (Mallard). Rare in spring and summer. Pair seen 8 July 1916 (Hanna 1917). One male seen 2829 May 1982, one bird on 10-12 July 1982, and another male seen 6 July 1985. Also rare at St. Lawrence Island (Sealy et al. 1971).

Anas clypeata (Northern Shoveler). Casual in spring. A pair was seen 1-3 June 1982. Casual in spring at St. Lawrence Island (Fay and Cade 1959; UAM unpubl. data).

Anas acuta (Northern Pintail). Uncommon or fairly common migrant; rare in summer, when possibly rare breeder. Klein (1959) reported 15 birds, which he said bred. Frequently observed in summer 1977 (DeGange and Sowls 1978). Present by 22 May 1982, up to 70 per day until 30 May, after which singles or groups of up to seven periodically mid-June to early 6 August. Lone male seen twice in July 1966 (D. Eisfeld pers. comm.); up to 10 on 5-6 July 1985; 10 flightless adults on 22 July 1997. During 9-12 August 1985 scattered birds seen, maximum a flock of $40+$. No suggestion of nesting during our fieldwork.

Anas crecca (crecca and carolinensis)
(Green-winged Teal). Rare migrant (both subspecies) and in summer. Hanna (1917) identified wings nailed to the wall of a derelict cabin. Species seen 23 May (1982) to 8 June (1982), sometimes paired, always few. Agonistic behavior between these forms seen 2 June 1982, when a male carolinensis chased an apparently paired male crecca, and the carolinensis flew off with the female. Summer records included a pair on 13 July 1985, three on 22 July 1986, four on 22 July 1997, and one 9 August 1985. Both subspecies are rare in spring and summer at St. Lawrence Island (UAM unpubl. data), where Sealy et al. (1971) suspected breeding.

Aythya ferina (Common Pochard). Casual in summer. Male seen 6-12 June 1982. Species is rare in spring in western Aleutians and casual in spring in the Pribilofs (Kessel and Gibson 1978); there is one record from St. Lawrence Island (UAM unpubl. data).

Aythya fuligula (Tufted Duck). Casual in summer. Male seen 3 July 1977 (DeGange and Sowls 1978). Species is very rare or casual north of the Aleutians, where it occurs in small numbers at any season (Kessel and Gibson 1978).

Aythya marila (ssp.) (Greater Scaup). Uncommon in spring and rare in summer. Reported 1 June 1944 (R. V. Anderson fide F. L. Beals); three noted in summer 1977 (DeGange and Sowls 1978). In subsequent years from 27 May (1982) to 6 July (1985), maximum 10 on 9 June 1983.

Polysticta stelleri (Steller's Eider). Uncommon in summer; nonbreeder. In 1977 five in basic plumage were seen on 30 June, 152 birds accompanied by two King and several Common eiders on 13 July, and five on 14 July (DeGange and Sowls 1978). A male on fresh water on 3 June was the only sighting in 1982. On 8 June 1983 a flock of $80+$ (mostly females, a few immature males) was first sighting of that summer, after which groups of 25 and 10 on 23 June and 25 June, respectively; species also noted on 3 and 5 July.

Somateria spectabilis (King Eider). Rare in summer; uncommon in winter. If Hanna's (1917) report accurate (abundant; evidently nesting), there has been a substantial change in status since 1916. Not seen by Gabrielson (1944) in July 1940 visit. DeGange and Sowls 
(1978) saw two in summer 1977. In 1982 two on 4 June on fresh water. Not recorded summers 1983 , 1985, or 1997. Identified in midwinter by McRoy et al. (1971:63), who on 67 February 1970 noted it and Common Eiders "in fair numbers, feeding in the open leads and flying restlessly back and forth, sometimes resting on the edge of the ice."

Somateria mollissima v-nigrum (Common Eider). Common breeder; uncommon in winter. Not recorded by Gabrielson (1944) on 89 July 1940. Nesting reported by Beals in 1944 and by Klein (1959), and an incubating female found 2 July 1966 (D. Eisfeld pers. comm.). In June and July 1977, when nested, paired on lakes and beach strands, also in rafts of 50-100+ offshore (DeGange and Sowls 1978). No evidence of breeding in 1982 or 1983, but paired birds seen, sometimes in lakeshore vegetation, and copulation on the ocean seen 15 June. Frequent in May and June 1983. Flocks of 22 on ocean 3 July 1985, of 16 on fresh water next day. Common breeder in July 1997, when young were seen. Reported in midwinter by McRoy et al. (1971), on 6-7 February 1970 (see King Eider).

Histrionicus histrionicus (Harlequin Duck). Fairly common throughout year; nonbreeder. Hanna (1917) saw a small flock 13 July 1916. Only on salt water, maxima 350-400 on $2 \mathrm{Au}-$ gust 1944 (F. L. Beals) and 200 in June to July 1977 (DeGange and Sowls 1978). With murres and Long-tailed Ducks, Harlequins were the most numerous birds observed 6-7 February 1970 (McRoy et al. 1971).

Melanitta perspicillata (Surf Scoter). Casual in spring and summer. Four on 31 May 1982 and flock of 25 on 22 July 1997. Species is casual in spring at St. Lawrence Island (UAM unpubl. data), accidental on Chukotsk Peninsula (Portenko 1973).

Melanitta fusca (ssp.) (White-winged Scoter). Casual in spring and summer. In 1982 two were seen 27 May, four on 31 May, seven on 11 June, and up to nine 8-15 June. A casual migrant at St. Lawrence Island (Sealy et al. 1971).

Melanitta nigra (americana) (Black Scoter). Casual in spring and summer. A male was seen 28 May 1982, and one bird on 9 June 1983. A casual migrant at St. Lawrence Island (Sealy et al. 1971).

Clangula hyemalis (Long-tailed Duck).
Common throughout the year. A very few nested in 1916 (Hanna 1917). Fledged young seen at end of July 1944 (F. L. Beals pers. comm.), in 1957 (Klein 1959), and in 1966 (D. Eisfeld pers. comm.). In 1982 copulation noted 28 May, courtship and territory defense 2 June, but no nests or young seen. In 1983 pairs in courtship and copulation on 5 June. Species present all winter 1943-1944 (R. V. Anderson fide F. L. Beals). With murres and Harlequin Ducks, Long-tailed Ducks were the most common birds seen 6-7 February 1970 (McRoy et al. 1971).

Bucephala albeola (Bufflehead). Casual in spring and summer. Up to three pairs seen 28 May to 4 June 1982. Two present 4-9 June 1983. Casual spring migrant at St. Lawrence Island (UAM unpubl. data).

Bucephala clangula (ssp.) (Common Goldeneye). Casual in spring and summer. Five to eight were present during July 1966 (D. Eisfeld pers. comm.), up to four 28 May to 16 June 1982, a pair on 9 June 1983, and two on 11 June 1986 (K. D. Schafer pers. comm.). Casual in spring at St. Lawrence Island (UAM unpubl. data).

Bucephala islandica (Barrow's Goldeneye). Casual or accidental in spring. Pair seen 2 June 1982. Casual in spring on coast of mainland western Alaska; unknown at St. Lawrence Island (UAM unpubl. data).

Mergus serrator (Red-breasted Merganser). Uncommon migrant and in summer. Reported as early as about 20 May (1944, R. V. Anderson fide F. L. Beals). DeGange and Sowls (1978) observed three in 1977. Up to three present 2 June to 12 July 1982 , a pair on 15 June 1983, six on 11 July 1986. Possible breeder at St. Lawrence Island (Sealy et al. 1971).

Circus cyaneus (ssp.) (Northern Harrier). Casual or accidental in spring. Female seen 23-25 May 1982. Species is apparently unknown at St. Lawrence Island.

Grus canadensis (canadensis) (Sandhill Crane). Rare or uncommon migrant and in summer; possible breeder. One seen 8-12 July 1916 by Hanna (1917, who did not report the species to be nesting cf. Gabrielson and Lincoln 1959:315); pair on 9 July 1940 inferred to be "evidently nesting" (Gabrielson 1944: 122) from midsummer presence. Recorded in small numbers in summer 1977 (DeGange and 
Sowls 1978). Present by 22 May (1982) and through at least 12 June (1983). Not clear if birds present continuously from mid-June to mid-July, but many sightings from 6 July (1985) to 20 July (1997), maximum a flock of 50 on 18 July 1997. Seven on 3 August 1982 and at least 10 present $14-19$ August 1985 were the only late-summer records. Maximum count in spring was flock of 70+ (22 May 1982).

Regular occurrence at St. Matthew probably represents the southern edge of annual movement between Alaska mainland and Chukotsk Peninsula; the bulk of this passage crosses the Bering Strait and northern Bering Sea from the Seward Peninsula and St. Lawrence Island to the Chukotsk Peninsula (Kessel 1984). Breeds on Alaska mainland coast (Brandt 1943, Gabrielson and Lincoln 1959, Shields and Peyton 1979, Woodby and Divoky 1983, Kessel 1989, Petersen et al. 1991), at St. Lawrence Island (Fay and Cade 1959, Sauer and Urban 1964), and at Nunivak Island (Swarth 1934) and breeds in northeastern Siberia in the Gulf of Anadyr (Vaurie 1965). In the Bering Sea south of St. Matthew only casual in the Pribilofs (Preble and McAtee 1923) and Aleutians (Byrd et al. 1974).

Pluvialis fulva (Pacific Golden-Plover). Common migrant; casual in midsummer, possible rare breeder. Conspicuous by 22 May 1982 and present through 6 June. Pair seen 30 June to 20 July 1966 "behaved as if breeding" (D. Eisfeld pers. comm.), and a pair on 4 July 1985 acted territorial. Earliest postbreeding migrants seen 18 July 1982, 19 and 24 July 1997, and 27 July 1944 (F. L. Beals pers. comm.), after which dates southbound individuals plentiful through observers' midand late-August departures. Species breeds at St. Lawrence Island (Fay and Cade 1959) and at Nunivak Island (Swarth 1934).

Charadrius mongolus (stegmanni) (Mongolian Plover). Casual in spring. Three or four seen 23 May to 3 June 1982. Rare migrant in the Aleutians and at St. Lawrence Island; species has nested on the Alaska mainland (Kessel and Gibson 1978).

[Charadrius hiaticula (Common Ringed Plover)]. Identified on 8 and 12 June 1982, including a bird at nest with two eggs. Both Palearctic hiaticula and Nearctic semipalmatus have nested at St. Lawrence Island (Sealy et al. 1971), so their distributions in the Bering Sea warrant close scrutiny. In the absence of substantiation, therefore, this species must be regarded as unconfirmed at St. Matthew. In Alaska south of St. Lawrence Island, $C$. hiaticula is known with certainty only as a casual migrant in the western Aleutians (see Byrd et al. 1978). Charadrius semipalmatus breeds as far west as the eastern Aleutians and the Pribilofs (UAM unpubl. data) and at St. Matthew (this paper).

Charadrius semipalmatus (Semipalmated Plover). Rare breeder. First recorded 1977, when species nested in small numbers (downy chick seen 14 July, DeGange and Sowls 1978). No arrival or departure information. Recorded 19 June 1982, and two adults seen with chick on 2 July 1982. First sighting in 1983 on 23 June; on 3 July pair observed in distraction display, but no young found; one adult seen 21 July. Pair at nest with two eggs 3 July 1985. One adult on 23 July 1985, an adult and two juveniles on 7 August, and an adult on 10 and 13 August. Two observed 9 July 1986. Adult female and downy chick (UAM 7743 and 7744) documented breeding 22 July 1997, when four adults seen.

Charadrius morinellus (Eurasian Dotterel). Casual or accidental in spring. One seen 28 May 1982. A trans-Bering Strait migrant to the Seward Peninsula and St. Lawrence Island (Kessel and Gibson 1978), but south of there known in Alaska only in fall in the western Aleutians (Gibson 1981).

Heteroscelus incanus (Wandering Tattler). Uncommon migrant. Reported by Beals (in 1944), Klein (1959), and DeGange and Sowls (1978). Present by 29 May (1982), spring maximum three on 2 June 1982. Earliest postbreeding migrants seen 22 July (1986), 25 July (1985), 29 July (1957, Klein 1959), and 2 August (1944, F. L. Beals), maximum four on 10 August 1986. Many tattlers were identified only to genus.

Heteroscelus brevipes (Gray-tailed Tattler). Rare migrant. Lone birds seen at intervals 29 May to 16 June 1982. Two seen 2-4 June 1983. Earliest postbreeding arrivals seen 25 July and 8-9 August 1983. Rare migrant on Bering Sea islands (Kessel and Gibson 1978).

Actitis hypoleucos (Common Sandpiper). Casual in spring. Two birds seen 7-9 June 
1982. Very rare spring migrant on Bering Sea islands (Kessel and Gibson 1978).

Numenius phaeopus (variegatus) (Whimbrel). Rare migrant. Reports without details in August 1954 (Rausch and Rausch 1968), of an unidentified curlew on 1 June 1982, and of a Whimbrel 18 August 1985 are recorded tentatively as this taxon, a rare or uncommon migrant in the western Aleutians (Gibson 1981) and at St. Lawrence Island (ibid.; UAM unpubl. data). Both Asiatic variegatus and North American N. p. hudsonicus have been recorded in the Pribilofs (Sladen 1966; UAM unpubl. data).

Limosa lapponica (baueri) (Bar-tailed Godwit). Uncommon migrant. Flock of 45 on 26 May 1982, flock of 21 on 3 August 1986, and about 15 in two flocks on 4 August 1986.

Arenaria interpres (interpres) (Ruddy Turnstone). Uncommon or fairly common in spring and common in fall; possibly has nested; an adult male on 13 July 1916 (Hanna 1917) was thought to be breeding. Numerous by 22 May 1982; most had moved on by 4 June. Earliest postbreeding, southbound birds on 3 July 1985, 8 July 1966 (D. Eisfeld pers. comm.), 9 July 1983, 11 July 1944 (Beals), 11 July 1982, and 12 July 1986, after which dates species present in flocks of up to 100 .

Arenaria melanocephala (Black Turnstone). Casual in spring. Up to five seen 2329 May 1982. A report without details in August 1954 (Rausch and Rausch 1968) is too vague for evaluation. Known from very few records west of its mainland Alaska breeding range (UAM unpubl. data).

Calidris pusilla (Semipalmated Sandpiper). Casual migrant. Five seen 26 May 1982, one on 3 August 1986, and one (UAM 5259) on 17 August 1985. Casual migrant west and south of its mainland-Alaska breeding range, in Pribilofs (Gabrielson and Lincoln 1959) and Aleutians (Gibson 1981).

Calidris mauri (Western Sandpiper). Uncommon migrant and breeder. One or two seen 30 June to 20 July 1966, behavior indicated nesting (D. Eisfeld pers. comm.). Distraction displays and other behavior pointed to nesting in 1977 (DeGange and Sowls 1978). Present by 22 May (1982) and latest 15 August (1985); small numbers $(<5)$ seen during most summers, whence one specimen (UAM 7340, adult female, 19 July 1997). Sea- sonal maxima 16 (27 May 1982) and 15 (11 August 1985). Common breeder at St. Lawrence Island (Sauer and Urban 1964, Thompson 1967). St. Matthew Island, Nunivak Island (Swarth 1934), and the Bering coast from the Yukon-Kuskokwim Delta (Gabrielson and Lincoln 1959) to the Alaska Peninsula (Gill et al. 1981) form southern limit of breeding range.

Calidris ruficollis (Red-necked Stint). Uncommon in fall. A few from 3 August (1986) to 17 August (1985), maximum 11 on $17 \mathrm{Au}$ gust 1985. Specimens: UAM 5253, immature female, and UAM 5258, immature male, both 14 August 1985 (PDM and R. Rohleder). Rare migrant on Bering Sea islands (Kessel and Gibson 1978).

Calidris minuta (Little Stint). Casual in fall. Two immatures identified in direct comparison with immature Red-necked Stint 16-18 August 1985; one remained through $21 \mathrm{Au}-$ gust (not 1986, cf. Gibson and Kessel 1992). Casual migrant in coastal Alaska from the Aleutians north (ibid.).

Calidris minutilla (Least Sandpiper). Rare breeder. Beals tentatively identified several in 1944, and Klein (1959) reported five during 29 July to 9 August 1957. In 1982 single birds on 27 May and 22 July. A worn adult on 21 July 1986, and an adult with a downy chick the same day. Breeds as far west as the eastern Aleutians (Gabrielson and Lincoln 1959, Murie 1959) and at least occasionally on the Pribilofs (UAM unpubl. data).

Calidris bairdii (Baird's Sandpiper). Rare migrant. Up to six birds 26 May to 7 June 1982. Earliest in fall on 6 August (1986); two on 9 August 1985 and one each on 13 and 15 August 1985. Reported during 2 August to 6 September 1954 (Rausch and Rausch 1968). Nests at St. Lawrence Island (Fay and Cade 1959, Sealy et al. 1971).

Calidris melanotos (Pectoral Sandpiper). Uncommon or fairly common migrant. Recorded 22 May to 2 June 1982, maximum 31 on 24 May. Earliest postbreeding migrants were three on 15 July (1986) and one on 16 July (1985); thereafter in small numbers through observers' late-August departures, maximum 12 on 15 August 1985. Reported during August 1954 (Rausch and Rausch 1968).

Calidris ptilocnemis ptilocnemis (Rock 
Sandpiper). Common breeder. "The most abundant bird of the level lands of the islands" in July 1916 (Hanna 1917:409), and still the most numerous breeding shorebird (DeGange and Sowls 1978; KW 1997 pers. obs.). Courtship, territorial defense, and much vocalization by 22 May 1982. Copulation and distraction displays first noted 31 May (1982). Two nests without eggs on 7 June 1982; a nest with full clutch of four on 8 June was subsequently preyed upon by foxes; many nests were later discovered to have been preyed upon. High incidence of nest predation in 1982 might have been influenced by low numbers of voles (Microtus). First chicks seen 12 July (1982), one a hatchling, another halfadult-sized. Late nest with two eggs on 21 July (1982), another of four eggs on 15 July (1986), and one nearly fledged downy chick on 24 July (1985). First fledgling seen 17 July 1986. Latest nest date was a hatching on 24 July 1997. These simultaneous, differing stages of the nesting cycle noted as long ago as 1944, when on 21 July Beals noted Rock Sandpipers "gathering in flocks; saw 24 near small lake in one group. Young from downy to flying seen daily. Some nests with eggs being hatched also observed today." One seen in 1982 had been color banded as an adult on the Yukon Delta in 1979.

Calidris alpina (ssp.) (Dunlin). Uncommon or fairly common migrant; possible breeder. Four on 8 July 1940 "acted as if they had nests" (Gabrielson 1944:125). Klein (1959) reported nesting in 1957; no Dunlins seen in summers 1966 (D. Eisfeld pers. comm.) or 1977 (DeGange and Sowls 1978). Twenty on 24 May 1982 and scattered observations during that summer; none in 1983. One adult 2125 July $1985,8-10$ on 4 August, one on 15 August. None in 1997. Common breeder at St. Lawrence Island (Fay and Cade 1959).

Calidris ferruginea (Curlew Sandpiper). Casual in fall. One juvenile on 14 August 1985. Casual migrant anywhere in the Bering Sea (Kessel and Gibson 1978).

Limnodromus scolopaceus (Long-billed Dowitcher). Uncommon migrant and in summer. Small groups of 4-6 during 22-31 May 1982, maximum 16 on 24 May. Two on 1 July 1982 were only midsummer record. Three adults on 1-2 August (1985) were earliest postbreeding migrants. Species has nested at St. Lawrence Island (Sealy et al. 1971).

Gallinago gallinago (Common Snipe) or $G$. delicata (Wilson's Snipe). Single snipe seen 22 and 24 May and 7 June 1982 were likely either Palearctic G. gallinago or Nearctic $G$. delicata. The former is a regular migrant in the western Aleutians (Byrd et al. 1978, Gibson 1981); the latter nests throughout mainland western Alaska (Gabrielson and Lincoln 1959).

Phalaropus lobatus (Red-necked Phalarope). Uncommon breeder. Abundant breeder in July 1916 (Hanna 1917), and Beals reported it so on 10 July 1944 and numerous immatures on ponds on 2 August. Gabrielson (1944) recorded at least 30 on 8 July 1940 and found a nest with four eggs. Klein (1959) recorded it in 1957, and it was probably breeding in summer 1966 (D. Eisfeld pers. comm.). Nested in small numbers in 1977 (DeGange and Sowls 1978). Earliest seen 28 May 1982, and present through July; pairs noted 6 June, copulation 7 June, and a nest with one egg 19 June.

Phalaropus fulicaria (Red Phalarope). Common migrant and in summer; rare breeder. Thousands flew past the ship, heading north, during 8-14 July 1916, "while we were in the ice in the vicinity of St. Matthew"; two flocks in surf on 11 July (Hanna 1917:409). Common at sea and near shore in 1977 (DeGange and Sowls 1978). First seen 25 May (1982), by 31 May in flocks of hundreds, flying about and feeding just offshore. Some still on passage 13 June 1982 (group of 16). Numbers dwindled by end of June; a nest with four eggs on 25 June 1982 is the only breeding evidence. Seen daily in early July 1985, on ocean and along beach, maximum flock of $20+$ on 6 July. Postbreeding birds as early as 8 July (1966; D. Eisfeld pers. comm.), after which date numerous.

Stercorarius pomarinus (Pomarine Jaeger). Uncommon migrant and in summer. Eight sightings in July 1977 (DeGange and Sowls 1978). Earliest on 26 May (1982) and 28 May (1983). Except for flock of 21, all sightings of singles or twos. At intervals in summer (one on 27 June 1982, two on 6 July 1985, two or three on 26 July 1986, one on 25 July 1997). Breeding range primarily north of Bering Strait (Gabrielson and Lincoln 1959). 
Stercorarius parasiticus (Parasitic Jaeger). Uncommon migrant and in summer. Most frequently observed jaeger in July 1977 (DeGange and Sowls 1978). Earliest on 28 May (1982), maximum four on 10 June 1982; except for two on 26 July 1982 none seen after 1 July (1982). One on 28 June was only report in 1983. In 1985 two on 5 July and singles on 17-19 July and 13 August. Two in August 1957 (Klein 1959). Breeds on Bering coast of Alaska mainland and throughout the Aleutians (Gabrielson and Lincoln 1959), but not on Bering Sea islands.

Stercorarius longicaudus pallescens (Longtailed Jaeger). Uncommon breeder. On 9 July 1940 a pair seen with two young not able to fly well (Gabrielson 1944). Two nests of two eggs found 8 July 1977 (DeGange and Sowls 1978). Species had arrived by 23 May 1982 and 29 May 1983; maxima in 1982 were five on 2 July and seven on 1 and 7 August. Breeds on Bering coast of Alaska mainland from Seward Peninsula to head of Bristol Bay, and on St. Lawrence and St. Matthew islands (Gabrielson and Lincoln 1959), but not on Alaska Peninsula or Aleutian Islands.

Larus ridibundus (Black-headed Gull). Casual in spring and summer. Recorded 3-8 June 1982, maximum three on 7 June. Adult observed 5 August 1985. Second-year bird on 12 and 18-21 July 1986. Rare in spring and very rare in summer in the Aleutians and Pribilofs (Kessel and Gibson 1978). Breeds as far north and east as the Bering coast of Kamchatka (Lobkov 1986).

Larus canus (ssp.) (Mew Gull). Casual in summer. One identified 7 August 1946 by Gabrielson (Gabrielson and Lincoln 1959); five seen 3 June 1982.

Larus argentatus (vegae) (Herring Gull). Rare in summer. Carcass of one molting into third-winter plumage found 4 August 1982. Second-year bird observed 23 July 1985 and a subadult on 4 August. One adult on 11 July 1986. This form breeds in small numbers at St. Lawrence Island (Fay and Cade 1959) and occurs there as a fairly common spring migrant (Thompson 1967).

Larus schistisagus (Slaty-backed Gull). Uncommon throughout year; possible breeder. Adult in colony of Glaucous and Glaucouswinged gulls on 9 July 1966 (D. Eisfeld pers. comm.), and third-year bird seen 26 June 1977
(DeGange and Sowls 1978). An adult and a less-than-adult seen 24 May 1982, and one seen 25 May. One present 26-27 May 1982, and three 2 July. Two noted 29 May 1983. Pair possibly nesting in summer 1982. One seen twice in July 1997. Breeds on Bering coast of Russia as far north as Koryak Highlands (Vaurie 1965); nesting recently recorded near Cape Romanzof, Alaska (McCaffery et al. 1997). Occurs in Bering Sea, Alaska, throughout the year (Kessel and Gibson 1978).

Larus glaucescens (Glaucous-winged Gull). Fairly common throughout year; breeds. Explicitly noted as absent by Hanna (1917). First recorded at St. Matthew during July 1966 by D. Eisfeld (pers. comm.), who noted "several nests in a Glaucous Gull colony on an islet at the northeastern shore." Four adults seen 26 June 1977, and an "immature" seen 13 July (DeGange and Sowls 1978). Almost daily in 1982, usually in flocks with Glaucous Gulls. On 7 July 1982 about 20 of 58 gulls seen were glaucescens; fledgling seen with two Glaucous Gull fledglings on 4 August. Breeding of this species among Glaucous Gulls seen in 1982, but not described. Three nests with young found among Glaucous Gulls on 24 June 1983. Breeding observed in 1997 (numbers not recorded) and approximately $50 \%$ of all hyperboreus and glaucescens observations (75-250 daily) identified to species were glaucescens. Observed west of St. Matthew Island in February 1970 (McRoy et al. 1971). Nesting reported at St. Lawrence Island in 1913 (Brooks 1915), but Fay and Cade (1959) and Sealy et al. (1971) regarded breeding status there as uncertain. Breeding colonies nearest St. Matthew are at Nunivak Island (Sowls et al. 1978). Northernmost breeding record in Russia is a pair comprising a glaucescens and a schistisagus that fledged young in 1977 at Geka Bay, at $60^{\circ} \mathrm{N}$ (near northern Karaginskiy Bay, on the Bering coast of Kamchatka; Kishchinskii 1980).

Larus hyperboreus pallidissimus (Glaucous Gull). Fairly common throughout year; breeds. Recorded nesting in 1916 (Hanna 1917), and a few nesting pairs seen 8 July 1940 (Gabrielson 1944). Population estimated at 2,000 and species regarded as a common breeder along entire coastline in 1977 (DeGange and Sowls 1978). Common breeding 
bird in 1982. Pairs on nests as early as 28 May (1983), eggs in nests by 4 June (1983), chicks first seen 24 June (1983), several 1-week-old chicks seen 7 July (1983), one 5- to 7-day-old chick seen 10 July (1982), first flight capable chicks seen 7 August (1983).

Xema sabini (Sabine's Gull). Uncommon in summer. Recorded by Hanna (1917), Gabrielson (1944), Beals (in 1944), DeGange and Sowls (1978), and Goetzmann and Sloan (1982). Seen as early as 1 June (1982) and as late as 12 August (1983 one adult), usually singly or in twos or threes; maximum a flock of five feeding offshore 15 July 1899 (Hanna 1917).

Rissa tridactyla pollicaris (Black-legged Kittiwake). Common breeder. Present in 1916 in colonies of a hundred to a thousand birds (Hanna 1917), and large colonies noted July 1940 (Gabrielson 1944). Populations breeding on cliffs of St. Matthew and Hall islands and Pinnacle Rock estimated in 1977 at 70,000 (DeGange and Sowls 1978). On nesting cliffs by late May (1980s), carrying nesting material 28 May (1982), and sitting on nests with no eggs 2 June 1982. Copulation noted 6 June (1982), first eggs 26 June (1982) and 3 July (1983 one each in six nests). Groups of up to 800 bathed in freshwater lakes almost daily in early summer, groups of only several hundred later in season, and flocks of up to 2,000 observed feeding inshore, often mixed with Red Phalaropes, particularly in early summer. On 26 July 1983, 26 of 55 nests were empty, 24 held one egg, two held two eggs, and three had a single chick; many eggs hatched 26-27 July; one nest held two eggs at least as late as 3 August (1983). Of 31 nests at one colony in 1983,10 produced eggs, but of those only four hatched, and when last observed on 2 August only one chick was still alive. Beals (in 1944) mentioned having seen no young by 13 August (he departed on 16 August). First chick in 1985 on 1 August probably hatched 31 July.

Rissa brevirostris (Red-legged Kittiwake). Casual or accidental in summer. Adult observed 15 August 1985. Recorded as far north as St. Lawrence Island (Sealy et al. 1971), but does not breed north of the Pribilofs.

Pagophila eburnea (Ivory Gull). Common in winter. On 26-27 March 1968 at ice edge southwest of St. Matthew, Irving et al. (1970:
111) noted "at dusk several flocks of 50 to 100 roosted in rather close groups on larger ice pans apart from the more scattered Glaucous Gulls." Two recorded near St. Matthew 6-7 February 1970 (McRoy et al. 1971).

Sterna hirundo (longipennis) (Common Tern). Casual in summer. One observed 2 June 1982, and maximum of four on 6 June 1982. Latest on 27 June 1982. Rare in spring and summer in the Aleutians and Pribilofs, casual as far north as St. Lawrence Island (Kessel and Gibson 1978). Widespread breeder in Kamchatka (Lobkov 1986).

Sterna paradisaea (Arctic Tern). Uncommon migrant and in summer; possible breeder. Recorded July 1899 by A. K. Fisher (Hanna 1917). Two seen in July 1966 in the island interior (D. Eisfeld pers. comm.). One seen 26 June 1977 (DeGange and Sowls 1978). In 1982 first noted on 1 June, maximum 10 on 3 June, last sighting on 26 June; one adult observed 16 August 1985. Breeds at St. Lawrence (Fay and Cade 1959) and Nunivak (Swarth 1934) islands, widely on the adjacent Alaska mainland (Gabrielson and Lincoln 1959), Chukotsk Peninsula (Portenko 1973), Koryak Highlands (Kishchinskii 1980), Kamchatka (Lobkov 1986), and the Aleutians (Murie 1959), but not in the Pribilofs.

Sterna aleutica (Aleutian Tern). Casual in spring and summer. Lone birds on 6 and 20 June 1982, maximum four on 26 June. Breeds locally in Aleutians (Kessel and Gibson 1978) and on Bering coasts of mainland Alaska (ibid.), Kamchatka (Lobkov 1986), and probably Chukotsk Peninsula (Portenko 1973). Pelagic away from colony sites; hardly known at Bering Sea islands (UAM unpubl. data), where it does not nest.

Alle alle (alle) (Dovekie). Rare probable breeder. Group of nine seen on the ocean 28 May 1982, and one or two on 12 and 24 June 1983 in auklet colonies. Species recorded 10 July 1985 in auklet colonies (Day et al. 1988). Also probable breeder at St. Lawrence and on islands in Bering Strait (Kessel and Gibson 1978).

Uria aalge inornata (Common Murre) and Uria lomvia arra (Thick-billed Murre). Abundant breeders. Both abundant in 1916 (Hanna 1917). Breeding population in 1977 estimated at 600,000 , in a ratio of 2.2 Thick-billed to 1 Common murre (DeGange and Sowls 1978). 
Beals (in 1944) reported that on 2 August he had still not seen young murres, and that only adults could be seen in nests on 16 August (just prior to his departure); none had hatched in 1977 prior to DeGange and Sowls's (1978) departure on 27 July. First eggs seen 16 July in 1982. Very small aalge chick (1-2 days old) seen 31 July (1985), and the first lomvia chick seen 2 August (1985). St. Matthew Island is the type locality of Uria aalge inornata.

Cepphus grylle (mandtii) (Black Guillemot). Uncommon in winter. Small numbers seen in leads in ice off St. Matthew on 7 February 1970 (G. E. Hall pers. comm., McRoy et al. 1971); most numerous bird in $95 \%$ ice cover between St. Lawrence and St. Matthew islands in March 1973, usually in ones or twos, maximum a flock of 40 on 4 March (G. J. Divoky pers. comm.). Latest departures in spring included single birds on 1 June 1982 and "most common guillemot in ice" near Hall Island on 8 June 1986 (K. D. Schafer pers. comm.). Because this species winters in Bering Sea pack ice (Kessel and Gibson 1978, Kessel 1989), but Pigeon Guillemot (Cepphus columba) retreats south of the ice in winter (Kessel 1989), small numbers of Cepphus in March 1968 near St. Matthew were likely this species, rather than $C$. columba as published (Irving et al. 1970).

Cepphus columba (Pigeon Guillemot). Fairly common breeder. Recorded in July 1899 by A. K. Fisher and in July 1916 by Hanna (1917), and described as common during July 1966 (D. Eisfeld pers. comm.). Breeding population estimated at 3,000 in 1977 (DeGange and Sowls 1978). Seen daily in July to August 1982 and 1997.

Synthliboramphus antiquus (Ancient Murrelet). Rare in summer. First seen 1 June 1982, maximum five on 8 June, latest on 24 June. Up to three seen 2-4 June 1983. Four basic plumaged birds seen 8 June 1986 in pack ice off Hall Island and two in alternate plumage 14 June 1986 (K. D. Schafer pers. comm.). Does not breed in the Bering Sea (Sowls et al. 1978), but occurs in summer and fall as far north as St. Lawrence Island (Bédard 1966, Sealy et al. 1971) and the Seward Peninsula (Kessel 1989).

Aethia psittacula (Parakeet Auklet). Common breeder. Hanna (1917) reported great numbers nesting, Gabrielson (1944:271) considered them to be "the most abundant auklet considerably outnumbering the other species in the parts ... that we explored," and Beals (in 1944) reported them breeding. Population estimated at 18,000 in 1977 (DeGange and Sowls 1978).

Aethia pusilla (Least Auklet). Abundant breeder. Hanna (1917) reported only four flocks and thought that a few might breed. Gabrielson (1944:272) described the species as common on 8-9 July 1940. Population estimated at 175,000 in 1977 (DeGange and Sowls 1978). Chicks first seen 19 July (1982).

[Aethia pygmaea (Whiskered Auklet)]. We disagree with Stresemann's (1949) contention (reiterated by Feinstein 1959 and American Ornithologists' Union 1998) that St. Matthew Island should be accepted as the type locality of this species. Gmelin's (1789) tenuous association of his Alca pygmaea with Pennant's (1785) "Pygmy Auk" resulted in the concomitant zoogeographic shortcomings of Stresemann's inference. The Kurile, Commander, and Aleutian islands encompass the Whiskered Auklet's range throughout the year (see Vaurie 1965, Byrd and Gibson 1980); in the Bering Sea it is known only from two records of occurrence at St. Lawrence Island and from one in Bristol Bay (Kessel and Gibson 1978). The species does not occur at St. Matthew, and there is no evidence that it ever has occurred there.

Aethia cristatella (Crested Auklet). Abundant breeder. Hanna (1917) reported it rare except for a large colony just south of Glory of Russia Cape. On the other hand, Gabrielson (1944) described it as fairly abundant on 8 July 1940. Breeding population estimated at 110,000 birds in 1977 (DeGange and Sowls 1978).

Cerorhinca monocerata (Rhinoceros Auklet). Casual or accidental in summer. A pair seen 9 July 1986 provides the northernmost report of this species. Breeds on both sides of the North Pacific (American Ornithologists' Union 1998), but, from the Kurile to the Shumagin islands, only locally in the Aleutians (Sowls et al. 1978, Byrd and Day 1986). Two at-sea records between the Aleutians and the Pribilofs (Gould et al. 1982; UAM unpubl. data) provide the only prior reports in the $\mathrm{Be}$ ring Sea. 
Fratercula corniculata (Horned Puffin). Common breeder. Large numbers reported by Hanna (1917). Population estimated to be 10,000 in 1977 (DeGange and Sowls 1978). Present by 22 May 1982, numbers increasing several days thereafter, present on cliffs 29 May; one seen carrying nesting material 18 June 1982. Breeds throughout Bering Sea (Gabrielson and Lincoln 1959).

Fratercula cirrhata (Tufted Puffin). Fairly common breeder. Many nesting colonies mentioned by Hanna (1917). Breeding population estimate to be 3,000 in 1977 (DeGange and Sowls 1978). Present on cliffs 29 May, carrying nesting materials 24 June 1982.

Cuculus canorus (canorus) (Common Cuckoo). Casual in summer. A gray morph Cuculus, identified as a Common Cuckoo by its white belly with faint ventral barring, was observed well on 16 June 1986 (K. D. Schafer pers. comm.). In spring 1986 migrant Common Cuckoos arrived at the end of May in the Aleutians, where the species was present through late June (UAM unpubl. data).

Nyctea scandiaca (Snowy Owl). Uncommon resident breeder. Albert K. Fisher saw several in July 1899 and found a nest with four young on 14 July (Hanna 1917). Present throughout summer 1944, maximum six (F. L. Beals). One on 7 July 1966 was the only observation that month (D. Eisfeld pers. comm.). One on 3 July 1977 and remains of another found 1 July were the only records during 26 June through 27 July 1977, a season of vole abundance (DeGange and Sowls 1978). One seen at intervals in summer 1982, when vole numbers low. One seen 11 June 1983, and another 19-20 July 1997. Seen on six occasions 7-27 March 1968 from icebreaker in pack ice, one on 22 March ca. 96 km from St. Matthew (Irving et al. 1970).

Asio flammeus (flammeus) (Short-eared Owl). Rare in spring and summer. One or two seen 24 May through 6 June 1982, one on 28 June 1983, and one on 31 July 1986. Has nested at St. Lawrence Island (Sealy et al. 1971).

Corvus corax (ssp.) (Common Raven). Rare in summer; probable breeder. Hanna (1917) saw about a dozen in July 1916, and Gabrielson (1944) saw one 8 July 1940. Not reported at all in summer 1944 (F. L. Beals). A few pairs seen from 23 May 1982 on, including two calling and one carrying nesting material at Bull Seal Point on 24 June. One seen 14 June 1986 (K. D. Schafer pers. comm.). Up to three seen 18-25 July 1997. Resident on St. Lawrence Island (Fay and Cade 1959, Johnson 1976), but species unknown at Nunivak (Swarth 1934).

Tachycineta bicolor (Tree Swallow). Casual in spring and summer. Up to three seen 2628 May 1982 and single birds on 21 and 30 June 1982. Has occurred widely and casually in Bering Sea (see Swarth 1934, Sealy et al. 1971).

Riparia riparia (riparia) (Bank Swallow). Casual in summer. One seen 20-21 June 1982. Casual at St. Lawrence Island (Fay and Cade 1959). Breeds annually as far southwest in Alaska as the eastern Aleutians (Kessel and Gibson 1978) and regularly reaches the Pribilofs in spring and summer (UAM unpubl. data).

Petrochelidon pyrrhonota (pyrrhonota) (Cliff Swallow). Casual in summer and fall. Single birds seen 28 June 1983 and 3 August 1985. Casual in the Aleutians and on Bering Sea islands (Kessel and Gibson 1978).

Hirundo rustica (ssp.) (Barn Swallow). Casual or accidental in summer. A white-bellied bird (gutturalis or rustica) seen 14 June 1986 (K. D. Schafer pers. comm.). Old World Barn Swallows are known in the Aleutians and at St. Lawrence Island (Kessel and Gibson 1978).

Delichon urbica (lagopoda) (Common House-Martin). Casual or accidental in fall. One seen at close range on 10 August 1983. Previously recorded on Seward Peninsula and Pribilofs (Hall and Cardiff 1978).

Phylloscopus borealis borealis (Arctic Warbler). Casual in summer. Single birds seen 9 July 1940 (Gabrielson 1944) and irregularly during 3-12 July 1985. Longer winged and larger billed than Alaska-breeding kennicotti, the only specimen seems to be this subspecies from northeastern Asia (UAM 5248, ad. male, 11 July 1985, B. A. Cooper).

Luscinia calliope (Siberian Rubythroat). Casual in summer. Single males seen 17-18 June 1982 and 9 July 1986. Rare spring migrant in western Aleutians (Gibson 1981), casual in Pribilofs (Kessel and Gibson 1978).

Oenanthe oenanthe (oenanthe) (Northern Wheatear). Casual in spring. One seen 24 May through 3 June 1982. Common intercontinen- 
tal migrant at St. Lawrence Island and Bering Strait (Kessel and Gibson 1978).

Catharus minimus (aliciae) (Gray-cheeked Thrush). Casual in spring and summer. One or two seen 5-15 June 1982. Scarce intercontinental migrant at St. Lawrence Island (Kessel and Gibson 1978).

Turdus obscurus (Eyebrowed Thrush). Casual in spring. One seen 6-7 June 1982. Rare in spring in western Aleutians (Kessel and Gibson 1978, Gibson 1981), casual in spring as far north as St. Lawrence Island (UAM unpubl. data).

Motacilla flava (ssp.) (Yellow Wagtail). Rare or uncommon in spring and fairly common in fall; rare in summer; possible breeder. Hanna (1917) saw a defensive pair on 13 July 1916 that acted as though breeding. Seen 28 May to 23 June 1982, maximum three, and on 24 June 1983. Autumn movement pronounced, earliest on 5 August (1985, 1986), maximum $55+$, in flocks of up to 24 , on 14 August 1985. Several on 17 August 1985 coincided with observers' departure. Widespread breeding form in Alaska is M. $f$. tschutschensis (Badyaev et al. 1998), but M. f. simillima, a regular spring migrant in western Aleutians (Gibson 1981), has nested at St. Lawrence Island (Sealy et al. 1971).

Motacilla alba (ocularis) (White Wagtail). Rare in spring and summer. Single birds seen 24 May 1982 through 14 June 1982 and on 2 July 1982 . Widespread, rare breeder in coastal western Alaska from Cape Lisburne to Seward Peninsula and St. Lawrence Island; has occurred on mainland as far south as Bristol Bay (Kessel and Gibson 1978).

Motacilla lugens (Black-backed Wagtail). Casual in spring. One seen 2 June 1983. Occurs annually in small numbers in western Aleutian Islands, where has nested, rare spring migrant at St. Lawrence Island, and has bred on the Seward Peninsula (Badyaev et al. 1996).

Anthus hodgsoni (yunnanensis) (Olivebacked Pipit). Casual in spring. Seen 3-11 June 1982, maximum 18 on 7 June. Spring 1982 brought large numbers to western Aleutian Islands (UAM unpubl. data). Casual spring migrant from western Aleutians to St. Lawrence Island (Kessel and Gibson 1978).

Anthus cervinus (Red-throated Pipit). Casual in spring. Single birds seen 27 May through 6 June 1982. Rare migrant through western Aleutians (Gibson 1981) and uncommon to fairly common breeder at St. Lawrence Island and in Bering Strait area (Kessel and Gibson 1978).

Seiurus noveboracensis (Northern Waterthrush). Casual or accidental in spring. One seen 6 June 1982. Other far western records include single June birds at St. Lawrence Island (Kessel and Gibson 1978) and on Chukotsk Peninsula (Portenko 1973), and one in August at Nunivak (Swarth 1934).

Passerculus sandwichensis (anthinus) (Savannah Sparrow). Casual in spring and summer. Hanna (1917) observed one 10 June 1916 in pack ice south of St. Matthew and another 13 July 1916 at Hall Island. One seen 6 July 1983, and one flew aboard ship just off St. Matthew on 29 August 1988 (J. L. Wells pers. comm.). Extralimital elsewhere west of breeding range in the Pribilofs (Gabrielson and Lincoln 1959), western Aleutians (Gibson 1981), at St. Lawrence Island (Sealy 1967), and on Chukotsk Peninsula (where it has recently nested; Morozov and Tomkovich 1980).

Calcarius lapponicus alascensis (Lapland Longspur). Abundant breeder. Gabrielson (1944) found it fairly common on 8 July 1940, but outnumbered by McKay's Bunting and Rock Sandpiper. Nest with four hatchlings and unhatched egg on 3 July 1985, a fledgling seen 19 July 1985. Fledglings taken or reported 18-25 July 1997, and on 26 July 1986.

Emberiza rustica (latifascia) (Rustic Bunting). Casual in spring. Seen 3-11 June 1982, maximum six on 6 June. Rare migrant in western Aleutians (Gibson 1981) and casual at the Pribilofs (UAM unpubl. data) and St. Lawrence Island (Kessel and Gibson 1978).

Plectrophenax nivalis (nivalis) (Snow Bunting). Uncommon in spring; possibly breeds. Common on observers' arrival 22 May 1982. Ratio of nivalis: hyperboreus on 27 May 1982 estimated to be 9:15, on 29 June 1982 $14: 23$; numbers of nivalis declined after beginning of June, however. On 24 June 1982 a McKay's Bunting routed a Snow Bunting in a chase and fight. Pair seen 11 June 1982, and on 23 July 1982 a pair acted as if they had a nest nearby but none was found. Not seen in 1983 or in 1997.

Plectrophenax hyperboreus (McKay's Bunting). Common breeder. Discovered to breed 
at St. Matthew in 1885 by C. H. Townsend (1887) and observed by all ornithologists in summer since. Arrives as early as " 10 or 11 March" (1944, R. V. Anderson fide F. L. Beals). From an icebreaker ca. $120 \mathrm{~km}$ east of St. Matthew, Irving et al. (1970) saw a few single birds and several small groups in flight toward the island on 20 March 1968.

Pairs and chase flights seen by 29 May (1982); female carrying nesting material 5 June (1983); nest building 18 June (1982); first eggs 23 June (1982); male carrying food to nest 15 June (1983), both parents carrying food to nest 26 June (1983), female carrying food to nest 30 June (1982); and first nestlings 28 June (1983: two 2- to 3-day-old nestlings) and 2 July (1982). Nests on 1 July 1983 had young almost ready to fledge. First fledglings 8-9 July 1940 (Gabrielson 1944), 8 July 1983 (adults feeding fledglings), 9 July 1966 (D. Eisfeld pers. comm.), and 13 July 1985. Several flight capable broods 12 July (1986), many of them 18-25 July 1997. Most nests in rock scree or holes in rock faces; one in mandible of a whale skull; a possible nest in voleexcavated hole. In 1982 nests held 3-5 eggs, commonly four. Flock of 12-15 fledglings 15 August 1985. On 2 July 1982 a female hyperboreus and a male nivalis were identified together. Winters on Alaska coast of Bering Sea from Seward to Alaska peninsulas (Kessel and Gibson 1978, and citations therein).

Fringilla montifringilla (Brambling). Casual in spring. One or two seen 1-3 June 1982. Annual migrant through western Aleutians (Gibson 1981), casual at Pribilof Islands and St. Lawrence Island (Kessel and Gibson 1978).

Leucosticte tephrocotis umbrina (Graycrowned Rosy-Finch). Uncommon breeder. Hanna (1917:409) wrote that a few "nest about most of the cliffs but they are much less common than on the Pribilof Islands." No arrival or departure information. Chase flights seen in late May (1980s); pairs seen in early June; carrying nesting materials to cliffs 8 June; male in courtship display 13 June 1982; no nests or young seen in 1982. Begging fledgling seen 26 July 1983. Adults feeding nestlings 14 July 1985; first fledglings that year on 14 August. Winter range not known. Note: a specimen attributed to St. Matthew Island in midwinter (USNM 234,230, male, "'22
February 1912") cannot have been collected in any winter month, for it is a black- not yellow-billed bird.

Loxia curvirostra (minor) (Red Crossbill). Casual in summer. A female or immature male was seen 5 August 1986. This species and subspecies has a history of casual occurrence on Bering Sea islands (see Thompson and DeLong 1969, Sealy et al. 1971).

Carduelis flammea flammea (Common Redpoll) and C. hornemanni (exilipes) (Hoary Redpoll). Rare or uncommon in summer; rare breeders. Both recorded, but discussed together because most redpolls not identified to species. Redpolls occur erratically, usually as ones, twos, or small flocks. Hanna (1917) reported a flock of four in July 1916, and Beals saw them at intervals throughout the summer of 1944. Klein (1959) reported over a dozen birds nesting in July and August 1957. Redpolls observed infrequently in May and June 1982; from 21 June almost daily, in flocks of up to 50-60 between late June and late July. Small numbers seen in July 1985, maximum five. A female on 28 June was the only record in 1983. About 10 on 11 July 1986, and a few seen July 1997, including a pair of C. flam$m e a$, taken in beach driftwood on 22 July, the female in laying condition (UAM 7748, oviduct greatly distended; incubation patch not yet edematous, largest ovum $4 \mathrm{~mm}$ ).

Carduelis pinus (pinus) (Pine Siskin). Casual in spring. Three seen 1-3 June 1982. Far west of breeding range, recorded previously in the Aleutians, Pribilofs, and at St. Lawrence Island (Kessel and Gibson 1978 and citations therein).

Coccothraustes coccothraustes (japonicus) (Hawfinch). Casual in spring. One seen 28 May 1982. Casual spring migrant in western and central Aleutian Islands (Kessel and Gibson 1978).

\section{DISCUSSION}

One hundred twenty-five species of birds have been recorded at St. Matthew Island. Thirty-one species breed (including annually, occasionally, once, and probably) and another eight are reported as possible breeders. The remaining 86 species occur either as passage migrants or visitants (birds neither migrating nor breeding). These totals are based on sporadic scientific visits to isolated St. Matthew 
and Hall islands during the 20th Century, and show that we have yet to determine the complete breeding avifauna, both annual and irregular, and to obtain a full appreciation of the annual variation in abundance (and success) of members of the breeding community. Further, we have only scratched the surface of the subject of the migrations to be observed here. The species composition of this avifauna, and its complexity in movements, breeding, and nonbreeding, reflect the interdigitation of the Old and New world migration systems in this region.

There are a number of obvious changes that have occurred in the fauna of these islands. Among the mammals, polar bears (Ursus maritimus) were discussed as common by Townsend (1887) and Elliott (1881; visited in 1874), and have not been noted in summer since. Arctic fox (Alopex lagopus) occurs naturally on the islands and undoubtedly has an effect on avian reproductive success. The endemic vole Microtus abbreviatus undergoes population cycles (Rausch and Rausch 1968). Reindeer (Rangifer tarandus) were introduced in 1944 and later died out (Klein 1968). We think it is unlikely, however, that any of these mammalian factors are related to the long term changes in avian populations observed on this island.

Given the conspicuous absence in 1916 and in the 1940s of the Glaucous-winged Gull, its common presence at St. Matthew since 1966 must be the result of a range expansion into the northcentral Bering Sea. The closely related Glaucous Gull is an ice-adapted arctic species whose southern breeding range limits parallel the extent of winter sea ice. The Glaucous-winged Gull is a North Pacific species that is not ice adapted, and the northern limits of its breeding range can be expected to be determined by the southern extent of icelocked, but otherwise appropriate, habitat at the beginning of the breeding season as St. Matthew was, for example, when Hanna arrived in 1916 in mid-June. This is precisely one species, therefore, that we would predict to show northward range expansion in the presence of climate change associated with global warming. It is noteworthy then that evidence of this northward range expansion and increase in abundance occur in conjunction with evidence for a northward retreat of the southern limit of summer sea ice in the arctic (Maslanik et al. 1996). St. Matthew is now one of the very few places where Glaucouswinged and Glaucous gulls breed sympatrically in any numbers. We suggest that further increases in mean ambient temperatures in this region might cause a decrease and eventual northward retreat from St. Matthew by the Glaucous Gull. In this regard it is important to note that the Glaucous Gull no longer breeds at its formerly southernmost breeding colony, on Walrus Island in the Pribilofs (Byrd 1997). St. Matthew Island is now the southernmost breeding colony of Glaucous Gulls in the Bering Sea islands.

The eiders present something of a puzzle, because it seems very unlikely that Hanna (1917) confused King and Common eiders. From the evidence, it seems that Common Eiders resumed a former (1899) presence following an absence of unknown duration (1916 at least), becoming a relatively common breeder on the island between 1916 and 19441954 and apparently maintaining this status to the present. Hanna's (1917:408) observations of King Eiders ("abundant" and "evidently nesting") is unparalleled elsewhere in the Bering Sea. If King Eiders nested on St. Matthew in 1916, this would represent the historic southernmost edge of the species' breeding range. Today the species is known here in summer only as a rare nonbreeder. There has been a decided change in abundance of the species in summer, and Hanna's (1917) observations of paired birds on fresh water do suggest breeding. This seems to indicate a northward retreat in midsummer abundance, which may represent a northward retreat of the species' breeding range.

Northern Pintails have shown fluctuating numbers, but this seems typical of the species in the region (e.g., see Fay and Cade 1959), and on St. Matthew this may be entirely due to vagaries of the locations of nonbreeding summer individuals. The Semipalmated Plover is a rather conspicuous bird that would have been difficult to miss had it been present as a breeder prior to 1977 . It seems to have been present in irregular numbers since. If this is not a recent range extension in the Bering Sea, as seems probable, the species has at least increased in abundance. The Red-necked Phalarope seems to have declined in abun- 
dance. Other, less common species may show differences simply due to happenstance. Those listed here, however, suggest genuine differences determined through the reports of a series of competent observers.

The list of species occurring on the island will undoubtedly increase with subsequent visits due to the occurrence of scarce migrants. Regular surveys and monitoring of the breeding species and their population levels might be a simple way to maintain a finger on the pulse of environmental shifts in this region. Because of its central geographic position, St. Matthew Island may represent an important bellwether for monitoring the effects of further global change in the northern Bering Sea.

\section{ACKNOWLEDGMENTS}

We thank the Inst. of Arctic Biology, Univ. of Alaska Fairbanks; the Alaska Maritime National Wildlife Refuge, U.S. Fish and Wildlife Service; and the consulting firm ABR, Inc., which conducted important biological reconnaissance and made collections on St. Matthew in the 1980s on a contract study funded by the USDI Minerals Management Service. The project also was supported by the National Science Foundation (NSF OPP-9725154 and NSF DEB-9981915). D. F. Murray and D. R. Klein provided helpful discussion and references, and the cheerful, hard-working personnel on the Alaska Maritime National Wildlife Service vessel M/V Tiglax deserve special thanks. Others whose observations contributed directly to this paper include G. V. Byrd, Jr., B. A. Cooper, G. J. Divoky, R. E. Gill, Jr., G. E. Hall, P. Klein, E. C. Murphy, R. Rohleder, D. G. Roseneau, K. D. Schafer, R. L. Scher, M. L. Ward, and R. P. Ward. We also thank B. Kessel for her role in establishing the Alaska bird observation archives at UAM. R. H. Day, B. Kessel, and S. G. Sealy made helpful comments on the manuscript.

\section{LITERATURE CITED}

AMERICAN ORnithologists' UnION. 1957. Check-list of North American Birds, 5th ed. Port City Press, Baltimore, Maryland.

AmERICAN ORnithologists' Union. 1998. Check-list of North American Birds, 7th ed. American Ornithologists' Union, Washington, D.C.

Badyaev, A. V., D. D. Gibson, And B. Kessel. 1996. White Wagtail (Motacilla alba) and Black-backed Wagtail (Motacilla lugens). Nos. 236-237 in The birds of North America. (A. Poole and F. Gill, Eds.). Academy of Natural Sciences, Philadelphia, Pennsylvania, and the American Ornithologists' Union, Washington, D.C.

Badyaev, A. V., B. Kessel, And D. D. Gibson. 1998. Yellow Wagtail (Motacilla flava). No. 382 in The birds of North America (A. Poole and F. Gill, Eds.). Academy of Natural Sciences, Philadelphia, Pennsylvania, and the American Ornithologists' Union, Washington, D.C.

BARnosky, C. W., P. M. ANDERSON, AND P. J. BARTLEIN. 1987. The northwestern U.S. during deglaciation: vegetational history and paleoclimatic implications. Pp. 289-321 in Geology of North America, vol. K-3: North America and adjacent oceans during the last deglaciation (W. F. Ruddiman and $\mathrm{H}$. E. Wright, Jr., Eds.). Geological Society of North America, Boulder, Colorado.

BÉDARD, J. 1966. New records of alcids from St. Lawrence Island, Alaska. Condor 68:503-506.

BRANDT, H. 1943. Alaska bird trails. Bird Research Foundation, Cleveland, Ohio.

Brooks, W. S. 1915. Notes on birds from east Siberia and arctic Alaska. Bull. Mus. Comp. Zool. 59: 361-413.

BYRD, G. V. 1997. Wildlife observations at Walrus Island, Pribilof Islands, Alaska, July 24, 1997. U.S. Fish and Wildl. Serv. Rep. AMNWR 97/14, Homer, Alaska.

BYRD, G. V. AND R. H. DAY. 1986. The avifauna of Buldir Island, Aleutian Islands, Alaska. Arctic 39: 109-118.

ByRD, G. V. AND D. D. GiBSON. 1980. Distribution and population status of Whiskered Auklet in the Aleutian Islands, Alaska. West. Birds 11:135-140.

Byrd, G. V., D. D. Gibson, AND D. L. Johnson. 1974. The birds of Adak Island, Alaska. Condor 76:288300.

Byrd, G. V., J. L. Trapp, and D. D. Gibson. 1978. New information on Asiatic birds in the Aleutian Islands, Alaska. Condor 80:309-315.

Day, R. H., A. R. DeGange, G. J. Divoky, and D. M. TrOY. 1988. Distribution and subspecies of the Dovekie in Alaska. Condor 90:712-714.

DeGange, A. R. And A. L. Sowls. 1978. A faunal reconnaissance of the Bering Sea National Wildlife Refuge, 26 June-27 July, 1977. USFWS Field Report 77-039, Anchorage, Alaska.

Dementiev, G. P. And N. A. Gladkov (Eds.) 1952. Birds of the Soviet Union, vol. IV. Israel Program for Scientific Translations, Jerusalem, Israel.

Douglas, H. AND K. Sowl. 1993. Northeastern extension of the breeding range of the Arctic Loon in northwestern Alaska. West. Birds 24:98-100.

Elliott, H. W. 1881. A monograph of the Pribylov group, or the seal-islands of Alaska. U.S. Govt. Printing Office, Washington, D.C.

Evans, M. E. AND W. J. L. Sladen. 1980. A comparative analysis of the bill markings of Whistling and Bewick's swans and out-of-range occurrences of the two taxa. Auk 97:697-703.

FAY, F. H. AND T. J. CADE. 1959. An ecological analysis of the avifauna of St. Lawrence Island Alaska. Univ. Calif. Publ. Zool. 63:73-150.

Feinstein, B. 1959. Geographic variation in the Whiskered Auklet. Auk 76:60-67. 
GABrielson, I. N. 1944. Some Alaskan notes. Auk 61: 105-130 and 270-287.

Gabrielson, I. N. AND F. C. Lincoln. 1959. Birds of Alaska. Stackpole, Harrisburg, Pennsylvania, and the Wildlife Management Inst., Washington, D.C.

Gibson, D. D. 1981. Migrant birds at Shemya Island, Aleutian Islands, Alaska. Condor 83:65-77.

GiBson, D. D. AND B. Kessel. 1992. Seventy-four new avian taxa documented in Alaska 1976-1991. Condor 94:454-467.

Gibson, D. D. And B. Kessel. 1997. Inventory of the species and subspecies of Alaska birds. West. Birds 28:45-95.

Gill, R. E., JR., M. R. Petersen, And P. D. Jorgensen. 1981. Birds of the northcentral Alaska Peninsula, 1976-1980. Arctic 34:286-306.

Gmelin, J. G. 1789. Systema Naturae I, vol. 2. Leipzig, Germany.

Goetzmann, W. H. And K. Sloan. 1982. Looking far North: the Harriman Expedition to Alaska. 1899. Princeton Univ. Press, Princeton, New Jersey.

Gould, P. J., D. J. Forsell, And C. J. Lensink. 1982. Pelagic distribution and abundance of seabirds in the Gulf of Alaska and eastern Bering Sea. FWS/ OBS-82-48, Biological Services Program, U.S. Fish and Wildlife Service, Anchorage, Alaska.

Hall, G. E. And E. A. Cardiff. 1978. First North American records of Siberian House Martin, Delichon urbica lagopoda. Auk 95:429.

Hamilton, T. D., K. M. Reed, And R. M. Thorson. 1986. Glaciation in Alaska: introduction and overview. Pp. 1-9 in Glaciation in Alaska: the geologic record (T. D. Hamilton, K. M. Reed, and R. M. Thorson, Eds.). Alaska Geological Society, Anchorage.

HannA, G. D. 1917. The summer birds of the St. Matthew Island Bird Reservation. Auk 34:403-410.

Irving, L., C. P. MCRoy, AND J. J. BuRns. 1970. Birds observed during a cruise in the ice-covered Bering Sea in March 1968. Condor 72:110-112.

Johansen, H. 1961. Revised list of the birds of the Commander Islands. Auk 78:45-56.

JoHnson, S. R. 1976. Spring movements and abundance of birds at Northwest Cape, St. Lawrence Island, Bering Sea. Syesis 9:31-44.

JONES, N. G. B. 1972. Moult migration of Emperor Geese. Wildfowl 23:92-93.

Kessel, B. 1984. Migration of Sandhill Cranes, Grus canadensis, in east-central Alaska, with routes through Alaska and western Canada. Can. FieldNat. 98:279-292.

Kessel, B. 1989. Birds of the Seward Peninsula, Alaska. Univ. Alaska Press, Fairbanks.

Kessel, B. And D. D. Gibson. 1978. Status and distribution of Alaska birds. Stud. Avian Biol. 1:1-100.

Kessel, B. And D. D. Gibson. 1994. A century of avifaunal change in Alaska. Stud. Avian Biol. 15:413.

KING, J. G. AND C. P. DAU. 1981. Waterfowl and their habitats in the eastern Bering Sea. Pp. 739-753 in The eastern Bering Sea shelf: its oceanography and resources, vol. 2 (D. W. Hood and J. A. Calder, Eds.). Office of Marine Pollution Assessment, National Oceanic and Atmospheric Administration, Juneau, Alaska.

KIsHChINSKII, A. A. 1980. Ptitsi Koryakskogo Nagor'ya [Birds of the Koryak Highlands]. Izdatel'stvo Nauka, Moscow, Russia.

KLEIN, D. R. 1959. Saint Matthew Island reindeerrange study. USFWS Special Scientific ReportWildlife No. 43, Washington, D.C.

KLEIN, D. R. 1968. The introduction, increase, and crash of reindeer on St. Matthew Island. J. Wildl. Manage. 32:350-367.

Kondratyev, A. Ya., N. M. Litvinenko, and G. W. KAISER (EDS.). 2000. Seabirds of the Russian Far East. Special Publication of the Canadian Wildlife Service, Ottawa, Ontario.

LoвKov, E. G. 1986. Gnezdyashchiesya ptitsi Kamchatki [Breeding birds of Kamchatka]. Akademiya Nauk SSSR, Vladivostok, Russia.

Maslanik, J. A., M. C. Serreze, and R. G. Barry. 1996. Recent decreases in arctic summer ice cover and linkages to atmospheric circulation anomalies. Geophys. Res. Letters 23:1677-1680.

McCAFFERY, B. J., C. M. Harwood, AND J. R. MoRGART. 1997. First breeding records of Slaty-backed Gull (Larus schistisagus) for North America. Pacific Seabirds 24:70.

McRoy, C.P., S. W. STOKer, G. E. Hall, AND E. MuKTOYUK. 1971. Winter observations of mammals and birds, St. Matthew Island. Arctic 24:63-64.

Morozov, V. V. AND P. S. Tomkovich. 1980. Gnezdovanie savannoi ovsyanki (Ammodramus sandwichensis) na Sovietskom Soyuze [Breeding of the Savannah Sparrow in the Soviet Union]. Zool. Zhurnal 59:1592-1593.

MurIE, O. J. 1959. Fauna of the Aleutian Islands and Alaska Peninsula. North American Fauna no. 61, U.S. Fish and Wildlife Service, Washington, D.C.

Murphy, E. C., B. A. Cooper, P. D. Martin, C. B. Johnson, B. E. LAwheAd, A. M. SPringer, AND D. L. Thomas. 1987. The population status of seabirds on St. Matthew and Hall islands, 1985 and 1986. Final Report for Minerals Management Service, OCS Study MMS 87-0043. Inst. Arctic Biology, Univ. of Alaska, Fairbanks.

Myneni, R. B., C. D. Keeling, C. J. Tucker, G. AsRAR, AND R. R. NEMANI. 1997. Increased plant growth in the northern high latitudes from 1981 to 1991. Nature (Lond.) 386:698-702.

Nelson, E. W. 1887. Birds of Alaska. Pp. 35-222 in Report upon natural history collections made in Alaska between the years 1877 and 1881 (H. H. Henshaw, Ed.), U.S. Army Signal Service Arctic Series 3, U.S. Govt. Printing Office, Washington, D.C.

Pennant, T. 1785. Arctic Zoology, vol. 2. Hughs, London, United Kingdom.

Petersen, M. R., D. N. Weir, And M. H. Dick. 1991. Birds of the Kilbuck and Ahklun Mountain Re- 
gion, Alaska. North American Fauna no. 76, U.S. Fish and Wildlife Service, Washington, D.C.

Portenko, L. A. 1973. Ptitsi Chukotskogo Poluostrova i Ostrova Vrangelya [Birds of the Chukotsk Peninsula and Wrangel Island], part II. Izdatel'stvo Nauka, Leningrad, Russia.

Preble, E. A. AND W. L. McAtee. 1923. Birds and mammals of the Pribilof Islands, Alaska. North American Fauna no. 46, Bureau of Biological Survey, Washington, D.C.

Rausch, R. L. AND V. R. Rausch. 1968. On the biology and systematic position of Microtus abbreviatus Miller, a vole endemic to the St. Matthew Islands, Bering Sea. Sonderdruck aus Z. f. Säugetierkunde 33:65-99.

RIDGWAY, R. 1886. Discovery of the breeding place of McKay's Snowflake (Plectrophenax hyperboreus). Auk 3:276-277.

Sauer, E. G. F. And E. K. Urban. 1964. Bird notes from St. Lawrence Island, Alaska. Bonn. Zool. Beitr. 15:45-58.

SEALY, S. G. 1967. Sight records of three new birds on St. Lawrence Island, Alaska. Murrelet 48:18.

SEAly, S. G., F. H. FAy, J. BÉdARD, AND M. D. F. UDVARDY. 1971. New records and zoogeographical notes on the birds of St. Lawrence Island, Bering Sea. Condor 73:322-336.

Shields, G. F. And L. J. Peyton. 1979. Avian community ecology of the Akulik-Inglutalik River delta, Norton Bay, Alaska. Pp. 150-205 in Principal investigators' reports, environmental assessment of the Alaskan continental shelf, biological studies, vol. 5. National Oceanic and Atmospheric Administration and the Bureau of Land Management, Boulder, Colorado.
Sladen, W. J. L. 1966. Additions to the avifauna of the Pribilof Islands, Alaska, including five species new to North America. Auk 83:130-135.

Sowls, A. L., S. A. HATCH, AND C. J. Lensink. 1978. Catalog of Alaskan seabird colonies. FWS/OBS78/78, Biological Services Program, Anchorage, Alaska.

Stresemann, E. 1949. Birds collected in the north Pacific area during Capt. James Cook's last voyage (1778 and 1779). Ibis 91:244-255.

Swarth, H. S. 1934. Birds of Nunivak Island, Alaska. Pac. Coast Avif. 22:1-64.

Thompson, C. F. 1967. Notes on the birds of the northeast cape of St. Lawrence Island and of the Punuk Islands, Alaska. Condor 69:411-419.

Thompson, M. C. And R. L. DeLong. 1969. Birds new to North America and the Pribilof Islands, Alaska. Auk 86:747-749.

TownSEND, C. H. 1887. Notes on the natural history and ethnology of northern Alaska. Pp. 83-101 in Report of the cruise of the Revenue Marine Steamer Corwin in the Arctic Ocean in 1885 (M. A. Healy, Ed.). U.S. Govt. Printing Office, Washington, D.C.

VAurie, C. 1965. The birds of the Palearctic fauna, non-passeriformes. H. F. and G. Witherby, London, United Kingdom.

Woodby, D. AND G. Divoky. 1983. Bird use of coastal habitats in Norton Sound. Pp. 353-704 in Final reports of principal investigators, environmental assessment of the Alaskan continental shelf, biological sciences, vol. 18. National Oceanic and Atmospheric Administration and the Bureau of Land Management, Juneau, Alaska. 